FARKAS TAMÁS - SLÍZ MARIANN szerk., Tulajdonnevek és szótárak. ELTE Magyar Nyelvtudományi és Finnugor Intézet - Magyar Nyelvtudományi Társaság, Budapest, 2020. 223-230. DOI: 10.26546/4892373.14

\title{
A Magyar földrajzi köznevek táráról
}

\begin{abstract}
1. A Magyar földrajzi köznevek tárának tudománytörténeti háttere és jelentősége. A földrajzi köznevek mint helyet jelölő kifejezések bármely nyelv szókincsének, így a magyarnak is a központi elemkészletébe tartoznak, a helyek fajtájának megjelölésére ugyanis kizárólag ezek az elemek alkalmasak. Érthető tehát, hogy a földrajzi köznevekkel kapcsolatos vizsgálatok a helynevek kutatásában mindenkor fontos szerepet töltöttek be. Ezért természetes az a jelenség is, hogy amikor a helynevekkel összefüggő feladatok a nyelvtudományban elötérbe kerültek, mindig erős figyelem fordult a földrajzi köznevek felé is (HOFFMANN 2000: 64). A szócsoport kutatásának fellendülését ily módon elsősorban a rendszeres helynévgyüjtés megindulásához, vagyis az élőnyelvi helynévi adatok felhalmozódásához köthetjük a magyar és a nemzetközi tudományosságban egyaránt (NEMES 2005: 4). A földrajzi köznevek kérdése mindamellett önmagában, azaz a helynevektől függetlenül is gyakran kerül a nyelvészeti vizsgálatok középpontjába (1. ehhez BÁBA 2016: 11-19).

A földrajzi köznevek tudományos igényü feldolgozásának alapvető feltétele az adott szócsoport adatainak lehető legteljesebb egybeállítása. Ennek köszönhető az, hogy nemcsak a hazai, hanem a nemzetközi névtudományban is fontos célnak tekintik a szakemberek a földrajzi köznevek állományának összegyüjtését és sokféle igényt kielégítő, jól kezelhető formában történő közreadását. Ezen a téren a szláv névkutatók járnak az élen: KISS LAJOS már a IV. Magyar Névtudományi Kongresszuson arról számolhatott be, hogy több szláv nyelv földrajziköznév-szótára is elkészült (KISS 1989). A Finn Névtani Archívum, amely két és fél millió, élőnyelvi gyüjtésből származó helynévadatot tartalmaz, ugyancsak lehetővé teszi a finn földrajzi köznevek együttes elemzését (MIIKKULAINEN 1996: 249). Korán jelentkezik az angol nyelvre vonatkozó földrajziköznév-gyüjtemény is, amelyet SWAYNE nevéhez köthetünk (1956). A magyar nyelvészeti kutatásokban évtizedekkel ezelött ugyancsak megfogalmazódott egy minél teljesebb földrajziköznévszótár összeállításának és közreadásának a gondolata.

A Magyar földrajzi köznevek tára (FKnT.) tehát hiánypótló munkának tekinthető, amely a helynévkutatást segítő gyakorlati hasznossága mellett további kutatási lehetőségeket is kínál. Anyagának felhasználásával mindenekelőtt pontosíthatóvá válik a helynevek helynévfajtákba rendezése, ami a helynévrendszerek nyelvészeti elemzésének alapvető feltétele. Ezt a nyelvi szempontú osztályozást ugyanis akkor végezhetjük el megnyugtatóan, ha ismerjük az ide tartozó elemek jelentéstartalmát, alá-, fölé- és mellérendeltségi

* A tanulmány az Emberi Erőforrások Minisztériuma ÚNKP-17-4 Új Nemzeti Kiválóság Programja és a Debreceni Egyetem támogatásával, az MTA-DE Magyar Nyelv- és Névtörténeti Kutatócsoport programja, valamint az MTA Prémium Posztdoktori Kutatóprogram keretében készült. Az írás alapvetően - célkitüzéséből adódóan - a Magyar földrajzi köznevek tára címü kötet (FKnT.) és a Földrajzi köznevek térben és időben címủ monográfia (Bába 2016) megfelelö egységeire, fejezeteire támaszkodik.
\end{abstract}


viszonyait. A névkutatás szempontjain túl a szótárnak szélesebb felhasználási lehetőségei is bőséggel vannak: a földrajzi köznevek nyelvtörténeti, etimológiai, nyelvföldrajzi célú vizsgálataiban e munkára egyaránt támaszkodhat a tudományos kutatás.

2. A szótár forrásai. A Magyar földrajzi köznevek tárát élönyelvi (táj)szótárként határozhatjuk meg, ezért összeállításakor elsősorban az Új magyar tájszótárt (ÚMTsz.) tekintettük vonatkozási pontnak. Ez a szótár a szélesebb értelemben vett 20. századi magyar nyelvet reprezentálja 1890-1960 közé eső források tájszóanyagának közreadásával. A Magyar földrajzi köznevek tárának bázisanyaga a célba vett szókincsréteg tekintetében azonban gazdagabb ennél, az elmúlt évtizedekben ugyanis regionális tájszótárak és földrajzinév-tárak egész sora látott napvilágot, amelyek így jelentősen kiegészítették az ÚMTsz. anyagát.

A földrajzi köznevek tára e fontos szómező minél teljesebb körü bemutatásával járulhat hozzá a vizsgálatok kiteljesítéséhez. Az ÚMTsz. ugyanis az 1960 előtti időszak nyomtatott, kéziratos, nyelvjárási és néprajzi természetü forrásaiban szétszórtan heverö tájszóanyagot ad közre, a földrajzi köznevek nagy tömegeit felszínre hozó földrajzinévtárak viszont éppen ezt követően láttak egyre bővülő számban napvilágot. Ez a körülmény azzal a fellendüléssel áll kapcsolatban, amely a magyar helynévkutatásban az 1960-as évek közepétől a helynévgyüjtés és a -közzététel terén tapasztalható volt, s amely - noha lendülete egyre inkább apad - máig sem szünt meg teljesen.

A megyénként, illetve járásonként, ritkábban kisebb tájegységenként, településenként közreadott helynévtárak a Somogy megye földrajzi nevei címü munkával (SMFN.) kezdődően rendszerint a területre jellemző földrajzi közneveket is közzéteszik. E szójegyzékeknek - mint maguknak a helynévgyüjteményeknek is - a színvonala azonban igen egyenetlen. Lexikográfiailag pontos, jól szerkesztett, megbízható kis szótárakat éppúgy találunk közöttük, mint olyan listákat, amelyekben érezhető a gyüjtő, a közzétevő bizonytalansága. Ebből adódóan pedig a bennük található adatok forrásértéke sem egyforma. A helynévtárak földrajziköznév-jegyzékeinek eltérő értéke többek között abból adódik, hogy a névgyüjteményeknek a földrajzi köznevek gyüjtésére vonatkozó alapelvei és módszerei sem voltak egységesek.

A Somogy megye földrajzi nevei címü kötet például nem a nevekből kiemelt földrajzi közneveket, hanem külön kérdőíves kikérdezéssel készült szólistát közöl (SMFN. 35-36). A munkát elvégző MARKÓ IMRE LEHEL ugyanis joggal vélte úgy, hogy a nyelvközösség földrajziköznév-anyaga nem feltétlenül fedi a tulajdonnevekben megjelenő földrajzi köznevek állományát. A tulajdonnevek között vannak például mesterségesen alkotott nevek is, amelyek nem az illető nyelvközösségtől származnak, így például a kataszteri térképet készítő mérnök kiegészítő névelemként olyan földrajzi köznevet is használhatott, amelyet az adott nyelvközösség akár nem is ismert. A Somogy megyei kötetben a földrajziköznévlista összeállítóinak törekvése ezért az volt, hogy a nyelvközösség közvetlen nyelvhasználatán alapuló köznevek kerüljenek a listába, ebböl adódóan pedig a földrajzi nevekben megjelenő, de közszói jelentésükben már kihalt elemeket (pl. mál) nem szerepeltették a jegyzékben. Az egyes címszavak értelmezései kapcsán arról is tudomást szerezhetünk a somogyi kötetből, hogy azok mindig a népi értelmezésen alapulnak, tehát semmiféle filológiai segédletet nem vettek hozzá igénybe a szerzők (SMFN. 35-36).

A Somogy megyei kötet elveit követve jelent meg a Tolna megye földrajzi nevei és a Baranya megye földrajzi nevei címü kötetekben is a földrajzi köznevek értelmező szótára (TMFN. 37-47, BMFN. 2: 951-958). Ettől némiképp eltért azonban a Veszprém megye 
földrajzi nevei címü kiadványsorozat munkamódszere. Itt ugyanis a földrajzi nevekben szereplő földrajzi köznevekből előzetesen összeállított listát kérdezték ki bizonyos kutatópontokon (VeMFN. 1: 15, VeMFN. 2: 15, VeMFN. 3: 16, VeMFN. 4: 20). További problémát jelent, hogy egyes földrajzinév-tárakban a földrajzi köznevek jelentésmeghatározása nem feltétlenül a helyi nyelvhasználat, hanem korábbi, máshol közölt definíciók alapján történt (vö. HOFFMANN 2003: 57).

A Magyar földrajzi köznevek tárának legfontosabb feladata az ÚMTsz.-éhez hasonlóan az, hogy a kutatót e szócsoport vizsgálatakor a számos forrás átnézése alól mentesítse, $\mathrm{s}$ a szókincs benne megjelenített elemeit úgy tárja elé, mintha ezt a munkát maga ténylegesen elvégezte volna. Mindez azonban reményeink szerint korántsem jelenti azt, hogy a forrásokhoz való hüség a tárat a mutató szintjére süllyeszti. A Magyar földrajzi köznevek tára csak olyan információt használhat fel, amelyet a forrás közöl, de - ahogyan ez jellemzi az ÚMTsz. gyakorlatát is - a források adta lehetőségeken belül általánosításokat, összevonásokat vagy éppen jelentésekre tagolásokat is megvalósít.

3. A földrajzi köznevek körének meghatározása. Az ÚMTsz. adatfeltárását követő időből több mint hetven további forrást (többségükben szójegyzékeket, kisebb számban tájszótárakból, tanulmányokból kiemelt anyagot) dolgoztunk fel, de beépítettük azoknak az 1960 előtt megjelent kiadványoknak (például a SzamSz.-nak, a SzegSz.-nek stb.) a földrajzi közneveit is, amelyekre az ÚMTsz. az egyes szócikkek végén utalt ugyan, de a konkrét anyagközlés különböző okok miatt elmaradt. Az így egybeállt földrajziköznév-tár csaknem 3500 szócikke több mint 18000 földrajzi köznévi adatot tartalmaz.

A felhasznált forrásokból azonban nem minden adatot vettünk figyelembe: a földrajzi köznevek kapcsán ugyanis komoly elhatárolási nehézségekbe ütközünk. A Magyar földrajzi köznevek tára összeállításakor azt a praktikus alapelvet igyekeztünk szem előtt tartani, hogy földrajzi köznévnek tekinthetünk minden olyan, helyet jelölö lexémát, amely a jelenkori helynevekben fajtajelölö szerepet tölt be, de egyúttal a helynevektöl függetlenül, közszói minőségében is funkcionál.

Az adattárba kizárólag fönévi szófajú elemeket emeltünk be. Nem vettük tehát figyelembe az általunk forrásként felhasznált gyüjtemények adatai között gyakran szereplő „földrajzi jelzőket” (alsó, közép, öreg stb.) és a szótárakban címszóként nemigen használatos szintagmákat (nagy állás, nagy árok stb.). Eljárásunk kapcsán ugyanakkor azt is hangsúlyoznunk kell, hogy elméleti szempontból a földrajzi köznevek fogalmának meghatározásakor nem húzhatunk meg e szócsoportot a nyelv más elemeitől elválasztó merev határokat, hiszen ez általában sem jellemző a nyelv egyes kategóriáira. Ez pedig azt jelenti, hogy a földrajzi köznév ugyan per definitionem fónévi jellegü lexikális elem, de átmenetet mutat más szófajok, illetve a szintagmák irányába (l. ehhez BÁBA 2012).

A földrajzi köznevek körének meghatározása során például az összetételek és a szintagmatikus kapcsolatok elhatárolása nem egy esetben komoly problémát jelent. A megyei és járási kötetek földrajziköznév-jegyzékébe, illetve tájszótárakba igen gyakran kerültek be olyan szintagmatikus formák, amelyek feltehetően gyakoriságuk folytán tünhetnek közszói jellegünek a névgyüjtők számára (vö. HEGEDÜs 2008: 130). NEMES MAGDOLNA doktori értekezésének mellékleteként közölt földrajziköznév-szótárában, amelynek fö forrásai éppen az elmúlt fél évszázadban készült helynévgyüjtemények voltak, csak a nagy jelző 44 különböző alaptaggal fordul elö (nagy árok, nagy lénia, nagy utca, nagy ág, nagy állás, nagy ér, nagy gát, nagy gyep stb.). Ezek gyakoriságát igazolja az a közvetlen tapasztalatunk is, hogy a Magyar Digitális Helynévtár több mint 250000 rekordnyi átvizsgált 
helynévanyagában a nagy híd szintagmatikus szerkezet például 70, a nagy árok 69, a nagy hegy 44 objektum neveként vagy névrészeként fordul elö. A Magyar földrajzi köznevek tárában az ilyen szerkezetü elemek földrajzi köznévi minősítésében fontos szempontként vettük figyelembe azt, hogy az elö- és utótag együttes jelentése egybeesik-e a szintagmatikus szerkezet jelentésével (pl. nagydomb 'nagyobb, magasabb kiemelkedés'), vagy az összetétel és a szerkezet jelentése eltér (pl. nagylegelö 'a falu közös legelöje'). Csak ez utóbbi esetben tekintettük földrajzi köznévnek az adott alakulatot (1. FKnT. 10).

Komolyabb nehézséget jelentenek az olyan, összetételgyanús csoportok, mint például az állatnévi előtagú struktúrák (pl. gulyaállás, gulyajárás), amelyek megítélése még a kiegészítő gyüjtések után is bizonytalan marad (HOFFMANN 2000: 69). A földrajzi nevek helyesírása címü kiadvány (FÁBIÁN-FÖLDI-HÖNYI 1998) ugyan részletes listát közöl a földrajzi köznévként kezelhető szavakról, s ebben a listában az összetett földrajzi köznevek számbavétele is megtörténik, ezek mindegyikének földrajzi köznévként való funkcionálása erősen kétséges (például sárkánygödör, sárkányjárás, ördöglyuk). Másfelöl nyilvánvaló, hogy a listába vett kifejezések analógiája alapján további, eddig nem adatolt összetételek megléte tételezhető fel, kérdéses azonban, hogy a lista kiterjesztése milyen határokon belül müködhet észszerüen. Póczos RITA hívja fel a figyelmet arra, hogy a Dinnyeföld, Csordakút típusú neveket a tipológiai munkák nem egységesen ítélik meg: néhol egyrészes névnek tekintik (mivel összetett földrajzi köznévböl alakult), néhol viszont kétrészes nevekként írják le öket (az utóbbi esetben csak a föld és a kút tartható bennük földrajzi köznévi elemnek). Ha a névadatokat a nyelvi környezetüket is figyelembe véve vizsgáljuk, az gyakran a kétrészesség mellett szól: ezeknek a helyneveknek ugyanis több esetben olyan szinonimáik vannak, amelyekkel utótagjukban megegyeznek, előtagjuk viszont a denotátum egy másik sajátosságát fejezi ki; pl. m. Vásár/tér $\sim$ Kocsmai/tér, Kender/föld Pajta/föld, n. Hanf/Acker Scheune/Acker (Póczos 2010: 59).

Az $-s$ képzős szavak esetében a nyelvhasználat és a nyelvszokás hiányos ismerete miatt szintén problémát jelenthet a földrajzi köznévi jelleg megítélése. Az $-s$ képzős helynevek ugyanis nemcsak földrajzi köznévböl keletkezhettek, hanem a fötag ellipszisével, illetve közvetlenül helynévképzéssel is (HoFFMANN 2000: 69). Az -s képzős köznevek és tulajdonnevek így sok esetben alakilag egybeesnek, és szétválasztásuk azért is különösen nehéz, mert a különböző jelentések etimológiailag is összefüggnek (BÉNYEI 2012: 94). BÉNYEI ÁGNES szerint az - $s$ képzős földrajzi köznevek esetében a gyűjtőnévképzői funkció szerkezeti változás eredményeképpen jött létre: a Nádas-tó-féle szerkezetből a jelző önállósul, és magára veszi az elmaradt fötag jelentését. A később létrejövő $-s$ képzős szavak azonban már nem tapadás útján, hanem a meglévők mintájára, eleve képzővel alakulnak (B. LŐRINCZY 1962: 91, KÁROLY 1970: 303, HOFFMANN 1993: 76, BÉNYEI 2012: 98). A legtöbb ilyen lexikai egység növénynévböl keletkezett (pl. bükkös, füzes, nádas, nyíres), de előfordulhat közöttük állatnévböl alakult is (pl. méhes) (vö. NEMES 2005, BÉNYEI 2012: 98). Ezeknek a lexémáknak a nyelvi státusával kapcsolatos kérdések helyesírási problémaként is jelentkeznek, hiszen az Alsó-nyíres/Alsó-Nyíres, Nagy-bükkös/Nagy-Bükkös nevek utótagjának írásmódját az határozza meg, hogy köznévnek vagy tulajdonnévnek tekintjük-e őket. Hozzá kell tennünk azonban, hogy a névadó és a névhasználó tudatában a földrajzi köznévböl, az ellipszissel, illetve a helynévképzéssel való alakulás nemigen válik el egymástól, így a névrész tulajdonnévi vagy közszói státusa sem lényeges számukra.

A földrajzi köznevek jelentéseinek, fogalmi tartományainak közös jellemzője, hogy helyet jelölnek. Az ebbe a fogalomkörbe való tartozás meghatározása azonban már önmagában sem egyértelmü, mert a helyfogalom igen sok szó jelentésének fontos összetevője. 
Ebben a vonatkozásban kínálhat gyakorlati szempontból hasznos fogódzót az a megközelítés, amely szerint földrajzi köznévnek csak azokat a helyjelölő szavakat tekinthetjük, amelyek - mivel a földrajzi köznevek a helynevek alkotásában lényeges szerepet játszanak a helyek fajtájának megjelölésére - helynévvel is megjelölhető helyfajtákat jelentenek. Kissé leegyszerüsítve pedig mindez azt jelenti, hogy az olyan, helyet jelölö közszavak, amelyek nem szerepelnek helynevekben, nem minősülnek földrajzi köznévnek (ágyás, gyalogjárda, veteményeskert stb.). A szótár anyagának egybeszerkesztésekor nem vettük figyelembe azokat az átvizsgált forrásokban előforduló szavakat sem, amelyek helynevekben viszonylag gyakoriak ugyan, de közszói absztrakciójú 'hely' jelentésük nincs (halesz, kütyü stb.) (HOFFMANN 2000: 71).

A jelentésen alapuló besorolást nehezíti az a körülmény is, hogy a szavak (így a helyet jelölök is) csak ritkán egyjelentésüek. A 'hely' jelentése egyes szavaknak (például az építményt, az intézményt vagy akár a növényt jelölöknek) másodlagosan is kialakulhat, így ezek a lexémák földrajzi köznévi jellegüvé válhatnak. Az épületeket jelölö neveket illetően az egyes helynévtárak sem képviselnek egységes gyakorlatot. A Mátészalkai (MJFN.) és a Nyírbátori járás (NyJFN.), valamint a Baranya megye földrajzi neveit tartalmazó kötetek (BMFN.) ezeknek az elemeknek csak egy részét (pl. a kocsma, csárda szavakat) vették fel a kötetben közreadott földrajziköznév-szótárba, ezzel szemben a Pápai és az Ajkai járás kötetei az autóbuszállomás, mentöállomás, iskola szavakat is tartalmazzák (VeMFN. 2-3; vö. NEMES 1999: 339). ${ }^{1}$ Az olyan lexémáknak, mint például az állomás, kocsma, kultúrház, kétségkívül van 'hely' jelentésük is. Ugyanakkor szemantikai tartalmuk központi magva HoFFMANN ISTVÁN szerint elsősorban más típusú szavakkal (mégpedig az építménynevekkel) füzi öket egy jelentésmezőbe, s az ezeket jelölő tulajdonnevek szintén csak másodlagosan tekinthetők helynévnek (2000: 68). Ezen megfontolások alapján nem tekintettük a földrajzi köznevek körébe tartozónak az olyan, épületet, illetve intézményt jelölö szavakat, mint az iskola, templom, imaház, ispotály, minthogy ezek csak másodlagosan jelölnek helyet. A belölük alkotott tulajdonnevek is elsődlegesen intézménynévnek tekinthetők.

Szintén gondot okozhatnak a földrajzi köznévi jelleg megítélését illetően az olyan épületeket, építményeket jelölő kifejezések, mint a kunyhó, esztena, istálló, akol, hodály stb. Ezek kapcsán ahhoz az alapelvhez tartottuk magunkat, hogy amennyiben az adott építmények egy-egy belterületi telek részét képezik, az azokat jelölö lexémákat nem tekintettük földrajzi köznévnek. Ha ellenben az akol, hodály stb. szavak a települések külterületén levő építményeket jelölik meg, felvettük őket a földrajzi köznevek tárába. Ezt a döntést föképpen az magyarázza, hogy a települések külterületén található építményeket jelölö lexémák igen gyakran részt vesznek a helynevek lexikális felépítésében, elsösorban mint fajtajelölö elemek.

A helynévi kategória egzakt meghatározásának hiánya olyan esetekben is gondot jelenthet, amikor az adott helymegjelölést szemantikai tartalma alapján ugyan a tulajdonnevek közé tartozónak ítélhetjük, azzal kapcsolatban azonban, hogy a kifejezés köznévi vagy tulajdonnévi jellegü-e, sokszor még maguk a névhasználók sem tudnak egyértelmüen állást foglalni; ilyenek például az Egyház földje egyház földje, Dobi Sándor tanyája (HBmHn. 1: 46, 47) stb. kifejezések. Ez a bizonytalanság pedig a helymegjelölésben szereplö földrajzi köznevek státusát is befolyásolja.

${ }^{1}$ Az egyes helyfajták eltérő mértékü képviseltségéről a földrajzinév-tárakban, illetve az ezzel kapcsolatos nehézségekről 1. HOFFMANN 2003: 45. 
A Magyar földrajzi köznevek tára azokat a (táj)szavakat tartalmazza, amelyeket a 20. század folyamán, illetve a mai magyar nyelvhasználatban a beszélők a különböző helyfajták megjelölésére használtak vagy használnak fel. Mivel azonban egy-egy terület élő helynévkincse hosszú történeti fejlődés során alakult olyanná, amilyennek ma ismerjük, természetes jelenség, hogy bármely helynévrendszer nagy számban tartalmaz olyan földrajzi köznévi lexémákat is, amelyek napjainkban már nem élnek közszóként az adott vidéken. Ennek megfelelően az egyes források által kihaló és régi minősítéssel ellátott földrajzi közneveket felvettük a földrajziköznév-tárba, a kihalt jelöléssel ellátottakat viszont mellőztük.

4. Kitekintés. A földrajziköznév-tár létrehozásának elméleti előzményét NEMES MAGDOLNÁnak az adott szókincsréteg jelenkori állományát feldolgozó doktori disszertációja (2005), valamint a történeti földrajziköznév-állomány rendszerszerü áttekintését célul kitűző PhD-értekezésem képezte (BÁBA 2013). A Magyar földrajzi köznevek tára címü kézikönyv közvetlen elözménye pedig az a szótár volt, amelyet doktori értekezéséhez NEMES MAGDOLNA állított egybe. E szótári állomány további források anyagával való kibővítését és megszerkesztését én végeztem el. Minthogy pedig a földrajzi köznevek állománya az egyik legkorábbról és leggazdagabban adatolható szócsoport, a feldolgozás következő fázisát egy olyan analitikus munka jelentheti, amely az egyes szavakra irányítja rá a figyelmet. Ennek a leginkább célszerü formája egy történeti-etimológiai földrajziköznév-szótár lehetne.

\section{Felhasznált források}

BMFN. = Baranya megye földrajzi nevei 1-2. Szerk. Pesti JÁnOs. Baranya Megyei Levéltár, Pécs, 1982.

FKnT. = BÁBA BARBARA - NEMES MAGDOLNA, Magyar földrajzi köznevek tára. A Magyar Névarchívum Kiadványai 32. Debreceni Egyetemi Kiadó, Debrecen, 2014.

HBmHn. = Hajdú-Bihar megye helynevei 1. A Hajdúböszörményi és a Hajdúhadházi járás helynevei. Szerk. BÁBA BARBARA. A Magyar Névarchívum Kiadványai 35. Debreceni Egyetemi Kiadó, Debrecen, 2015.

MJFN. = KÁLNÁSI ÁRPÁD, A mátészalkai járás földrajzi nevei. KLTE Magyar Nyelvészeti Tanszék, Debrecen, 1989.

NyJFN. = JAKAB LÁSZLÓ - KÁLNÁSI ÁRPÁD, A nyírbátori járás földrajzi nevei. Nyírbátor Városi Tanácsa, Nyírbátor, 1987.

SMFN. = Somogy megye földrajzi nevei. Szerk. PAPP LÁsZLÓ - VÉGH JÓZSEF. Akadémiai Kiadó, Budapest, 1974.

SzamSz. = CsÜRY BÁLINT, Szamosháti szótár 1-2. Magyar Nyelvtudományi Társaság, Budapest, 1935-1936.

SzegSz. = BÁLINT SÁNDOR, Szegedi szótár 1-2. Akadémiai Kiadó, Budapest, 1957.

TMFN. = Tolna megye földrajzi nevei. Szerk. ÖRDÖG FERENC - VÉGH JÓZSEF. Akadémiai Kiadó, Budapest, 1981.

ÚMTsz. = Új magyar tájszótár 1-5. Főszerk. B. LŐRINCZY ÉVA. Akadémiai Kiadó, Budapest, 1979-2010.

VeMFN. = Veszprém megye földrajzi nevei 1 -4. Szerk. BALOGH LAJOS - ÖRDÖG FERENC [-VARGA MÁRIA]. A Magyar Nyelvtudományi Társaság Kiadványai 156, 171, 192, 194. Budapest, Magyar Nyelvtudományi Társaság, 1982-2000. 


\section{Hivatkozott irodalom}

BÁBA BARBARA 2012. A földrajzi köznév fogalma. Helynévtörténeti Tanulmányok 8: 121-131.

BÁBA BARBARA 2013. Vizsgálatok a földrajzi köznevek története köréböl. Doktori (PhD) értekezés. Debreceni Egyetem, Debrecen. Kézirat.

BÁBA BARBARA 2016. Földrajzi köznevek térben és időben. A Magyar Névarchívum Kiadványai 39. Debreceni Egyetemi Kiadó, Debrecen.

BÉNYEI ÁGNES 2012. Helynévképzés a magyarban. A Magyar Névarchívum Kiadványai 26. Debreceni Egyetemi Kiadó, Debrecen.

FÁBIÁN PÁL - FÖLDI ERVIN - HŐNYI EDE 1998. A földrajzi nevek helyesírása. Akadémiai Kiadó, Budapest.

HEGEDŰS ATTILA 2008. Jel és jelentés a földrajzi köznevekben. In: GECSÖ TAMÁs - SÁRDi CSILLA szerk., Jel és jelentés. Segédkönyvek a nyelvészet tanulmányozásához 83. Tinta Könyvkiadó, Budapest. 129-133.

HoffMANN IsTVÁn 1993. Helynevek nyelvi elemzése. A Debreceni Kossuth Lajos Tudományegyetem Magyar Nyelvtudományi Intézetének Kiadványai 61. Debreceni Kossuth Lajos Tudományegyetem Magyar Nyelvtudományi Intézet, Debrecen.

HOFFMANN ISTVÁN 2000. Földrajzi közneveink szótáráról. In: SZABÓ GÉZA - MoLNÁR ZOLTÁN szerk., Nép - nyelv - társadalom. Végh József emlékezetére. A Berzsenyi Dániel Főiskola Magyar Nyelvészeti Tanszékének Kiadványai 4. Berzsenyi Dániel Főiskola, Szombathely. 63-73.

HoffMAnN IsTVÁN 2003. Magyar helynévkutatás. 1958-2002. A Magyar Névarchívum Kiadványai 7. Debreceni Egyetem Magyar Nyelvtudományi Tanszék, Debrecen.

KÁROLY SÁNDOR 1970. Általános és magyar jelentéstan. Akadémiai Kiadó, Budapest.

KISS LAJOS 1989. Az európai névtudomány utóbbi másfél évtizede. In: BALOGH LAJOS - ÖRDÖG FERENC szerk., Névtudomány és müvelödéstörténet. A IV. magyar névtudományi konferencia elöadásai Pais Dezső születésének 100. évfordulóján. (Zalaegerszeg, 1986. október 8-10.). A Magyar Nyelvtudományi Társaság Kiadványai 183. Magyar Nyelvtudományi Társaság, Budapest. 18-31.

B. LŐRINCZY ÉVA 1962. Képzö- és névrendszertani vizsgálódások. Az-s -cs képzővel alakult névanyag az ómagyar korban. Nyelvtudományi Értekezések 33. Akadémiai Kiadó, Budapest.

Mitkkulainen, Raija 1996. The Database of Finnish Toponyms. In: Nicolaisen, Wilhelm FrITZ HERMANN ed., Proceedings of the XIXth International Congress of Onomastic Sciences. Aberdeen, August 4-11, 1996. 1-2. University of Aberdeen, Department of English, Aberdeen. 2: $248-255$.

NeMES Magdolna 1999. A földrajzi köznevekröl. Magyar Nyelvjárások 37: 331-340.

Nemes Magdolna 2005. Földrajzi köznevek állományi vizsgálata. Doktori (PhD) értekezés. Debreceni Egyetem, Debrecen. Kézirat.

Póczos RiTA 2010. Nyelvi érintkezés és a helynévrendszerek kölcsönhatása. A Magyar Névarchívum Kiadványai 18. Debreceni Egyetemi Kiadó, Debrecen.

SWAYNE, JAMES COLIN 1956. A concise glossary of geographical terms. George Philip and Son, London.

BÁBA BARBARA

ORCID: https://orcid.org/0000-0002-2381-5216

Debreceni Egyetem

Bölcsészettudományi Kar 


\section{BARBARA BÁBA, On the Dictionary of Hungarian geographical common nouns}

Geographical common nouns as elements that denote places are a central element of the lexicon of any language. The same can be said for Hungarian, as these are the only words suitable to designate the type of a place. Naturally, research into the nature of geographical common nouns has always been central to the study of toponyms. The base of such work is the academic collection of the highest possible number of such common nouns and their publication in an easy to use and accessible form. Projects of this nature have been the focus of both Hungarian and international onomastic research. The Dictionary of Hungarian geographical common nouns is thus a vital work, which not only provides practical support for the study of toponyms but raises unique research questions. 